\title{
D-20 GEOCHEMICAL AND STRATIGRAPHIC EVOLUTION OF THE MEDITERRANEAN IN THE LATE MIOCENE
}

R. FLECKER ${ }^{182}$, R.M. ELLAM ${ }^{2} \& \dot{\text { W. KRIJGSMAN }}{ }^{3}$

${ }^{7}$ Cambridge University, Department of Earth Sciences, Downing Street, Cambridge CB2 3EQ, UK. ${ }^{2}$ Scottish Universities Environmental Research Centre

${ }^{3}$ Paleomagnetic laboratory Fort Hoofddijk

\begin{abstract}
Despite decades of research, no consensus hypothesis for the cause of the Messinian Salinity Crisis has been reached; efforts are hampered by the lack of modern analogues for the saline giants. Recent research has illustrated the importance of pre-evaporite sediments in understanding the nature of the Mediterranean in the prelude to salt precipitation. However, contradictions between various geological datasets persist. Compilation of a Mediterranean wide Sr isotope dataset permits the temporal and spatial distribution of normal and anomalous ${ }^{87} \mathrm{Sr} /{ }^{86} \mathrm{Sr}$ from late Miocene sediments to be displayed. The results suggest that the development of the typical Mediterranean stratigraphy is associated with a $\mathrm{Sr}$ isotope record connected to the global ocean until the deposition of the Upper Evaporites. In other areas both the stratigraphic and $\mathrm{Sr}$ isotope records are anomalous up to several million years prior to salt deposition. Initial interpretation of these results suggests that there is a strong link between major lithological changes and regional transgression events.
\end{abstract}

\section{Introduction}

The typical Late Miocene stratigraphic sequence in the Mediterranean represents the transition from marine carbonates to evaporites to brackish-water clastics (Fig. 1). This lithological progression can be recognized in many parts of the Mediterranean and is thought to reflect the gradual restriction of the oceanic link between the Atlantic and the Mediterranean as a result of ongoing collision of Africa and Eurasia (Hsü et al., 1977). Recent work demonstrated that it is possible to correlate Messinian marl-limestone cycles and their equivalents in the evaporites over hundreds of kilometres within the Mediterranean Basin (Krijgsman et al., 1999). This cyclicity has been interpreted as a $\sim 20,000$ year response to precession in a basin sufficiently restricted to amplify the local climatic signal.

The main lithological changes are abrupt. Originally this observation led to the assumption that the initiation of evaporite precipitation could not beattributed to climatic change. Instead, tectonically induced isolation was invoked (Hsü et al., 1977). Later however, published Sr isotope data from the evaporites demonstrated that the Lower Evaporites precipitated from seawater connected to the Atlantic (Müller and Mueller, 1991). More recently ${ }^{87} \mathrm{Sr} /{ }^{86} \mathrm{Sr}$ extracted from Late Tortonian and

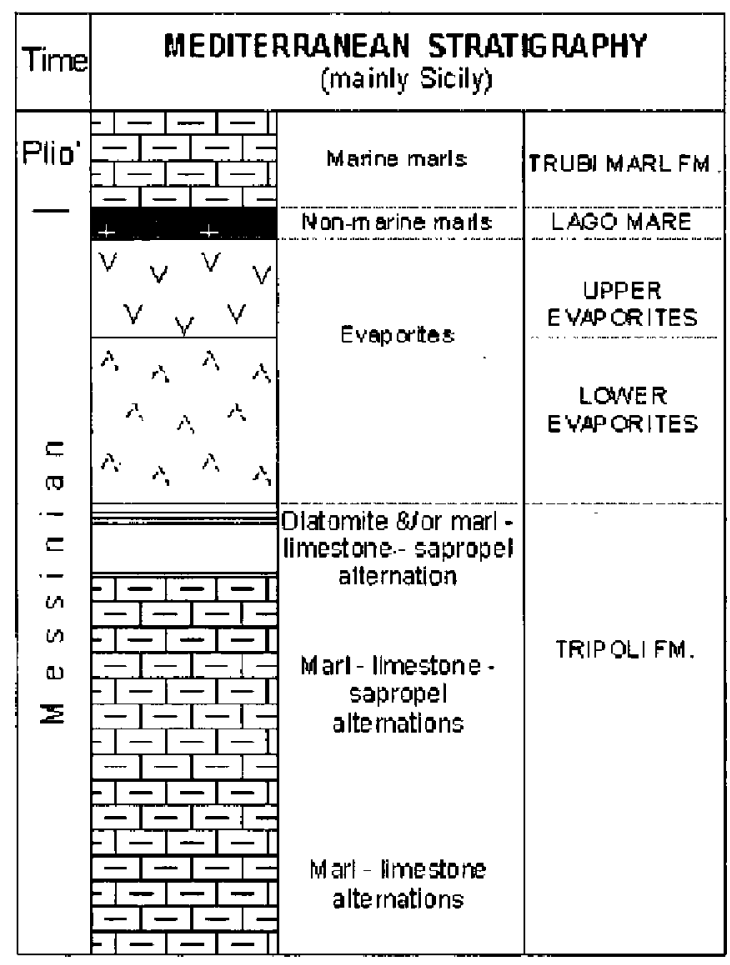

Figure 1. Simplified late Miocene stratigraphy of the Mediterranean 


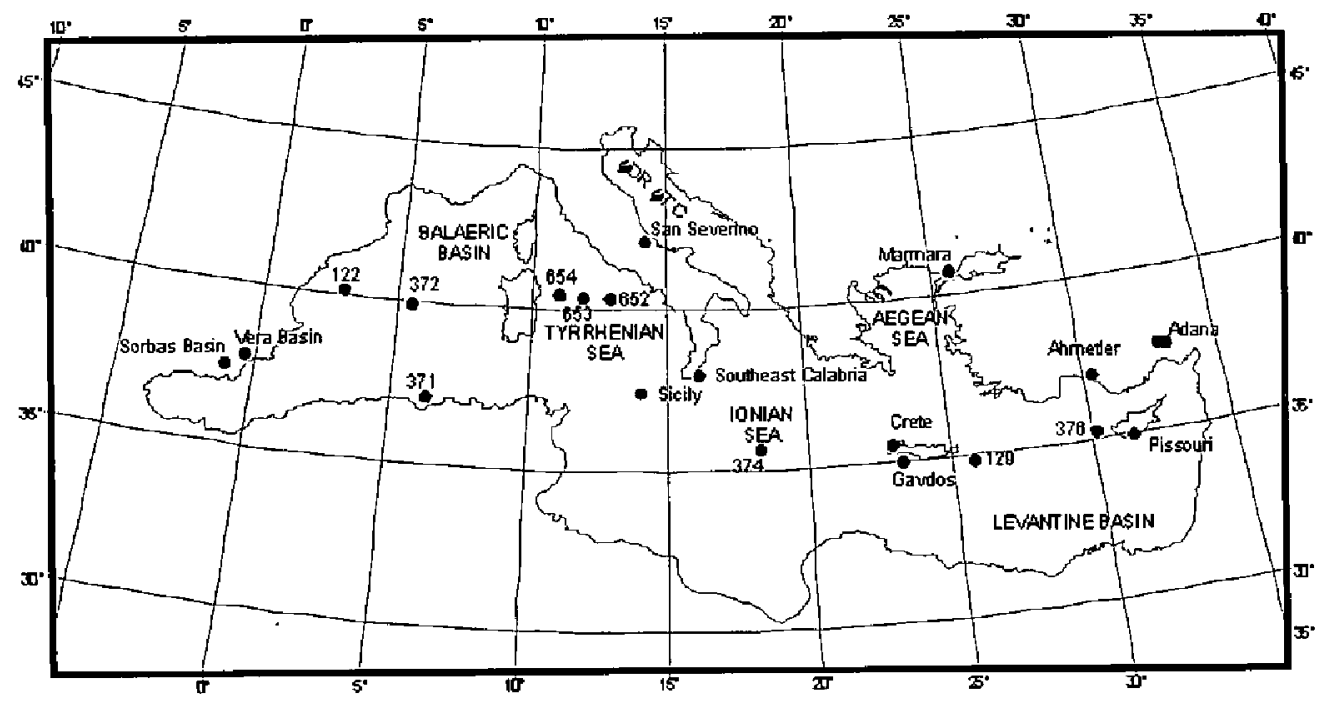

Figure 2. Location map of all the published Sr data for Late Miocene-Pliocene sediments in the Mediterranean.

Messinian foraminifera have been interpreted as suggesting that isolation of parts of the Mediteranean may have occurred several million years before the first salt was deposited (Flecker and Ellam, 1999).

Clearly, the relationship between lithology, climate, tectonics and connectivity is not simple. This study aims to combine lithological and geochemical datasets by synthesising the data available both for the entire Mediterranean and on a basin-by-basin basis. The $\mathrm{Sr}$ isotope dataset for Late Miocene Mediterranean sediments is currently limited both spatially (Fig. 2) and temporally. Data from sediments beneath the evaporites are particularly sparse and to date, no analyses from sections displaying the marllimestone precessional cycles have been published. In this paper we contribute to the geochemical dataset with analyses of samples predating salt from two sections, Pissouri in Cyprus and Gavdos south of Crete (Fig. 2). These have both been studied and correlated using astronomical cyclicity (Krijgsman et al., 1995). The new ${ }^{87} \mathrm{Sr} /{ }^{86} \mathrm{Sr}$ are combined with published data to provide 6 time-slice maps illustrating the $\mathrm{Sr}$ isotope evolution of the Mediterranean from Tortonian to Pliocene.

\section{Method}

The $\mathrm{Sr}$ isotope composition of seawater has changed throughout geological history and is dependent on the balance between the various $\mathrm{Sr}$ fluxes. However, at any one time all the oceans have identical ${ }^{87} \mathrm{Sr}{ }^{86} \mathrm{Sr}$ (DePaolo and Ingram, 1985). Isolation of marginal basins results in deviation away from global oceanic ${ }^{87} \mathrm{Sr}{ }^{86} \mathrm{Sr}$ towards a composition influenced strongly by the ${ }^{87} \mathrm{Sr} /{ }^{86} \mathrm{Sr}$ of rocks in the drainage hinterland (Albarede and Michard, 1987; Müller and Mueller, 1991).

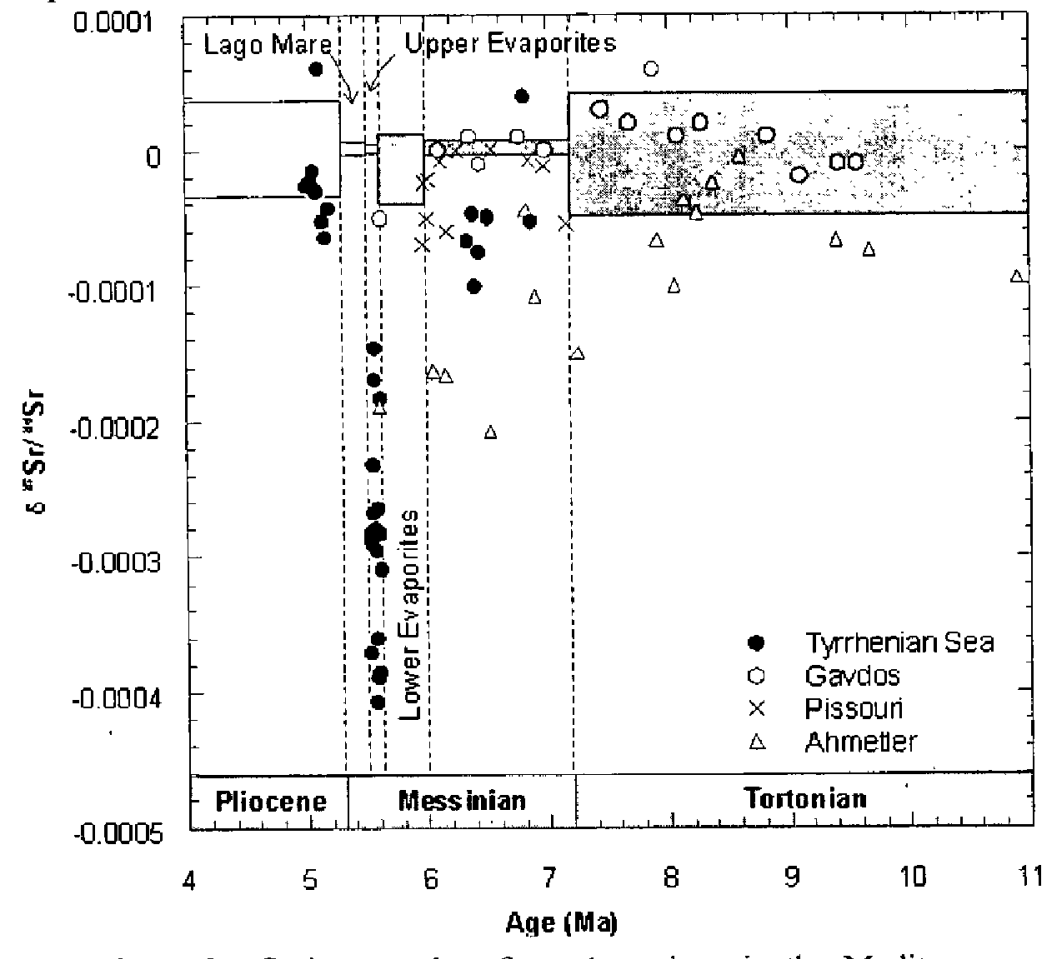

Figure 3. Sr isotope data from 4 sections in the Mediterranean plotted as a function of difference to average coeval ocean values (Howarth and McArthur, 1997). Tyrrhenian Sea data derived from (Müller and Mueller, 1991; Müller et al., 1990); Ahmetler data from (Flecker and Ellam, 1999). Lithological and stratigraphic boundaries are taken from (Berggren et al., 1995; Krijgsman et al., 1999). 
Hence, connection or isolation between marginal basins and oceanic circulation can be determined from $\mathrm{Sr}$ isotope data. The major rivers feeding the Mediterranean (e.g. Nile, Rhone, Ebro, Tiber) carry significantly lower strontium isotope ratios than either current global ocean values or the relatively narrow range of values that characterised the Late Miocene (Palmer and Edmond, 1989). If we assume that the drainage hinterland of these rivers has not changed significantly during the last $5 \mathrm{Ma}$ (Brass, 1976), isolation of the Mediterranean in the Late Miocene, as today, would result in a deviation away from global ocean values towards lower ${ }^{87} \mathrm{Sr} /{ }^{86} \mathrm{Sr}$.

Numerous studies have demonstrated that reliable sea-water Sr isotope records can be extracted from foraminifera providing care is taken to exclude foreign material (Hess et al., 1986; Palmer and Elderfield, 1985). Foraminiferal samples were hand-picked from washed and sieved whole-rocks and subject to standard cleaning and analytical procedures.

\section{Results}

To obtain a Sr isotope record for the sections on Gavdos and Cyprus, foraminifera were picked from marl horizons beneath the lower evaporites. These sediments span an interval between $5.96+/-0.02 \mathrm{Ma}$ (Krijgsman et al., 1999) and around 9.5 Ma (Krijgsman et al., 1995). All the Gavdos samples are within error of the ocean water curve within the same magnetostratigraphic interval (Fig. 3). Deviation from the oceanic values (the shaded boxes) in the Cyprus data only occurs at the top of the section in the evaporites and the sediments that underlie them. Here the $\delta^{87} \mathrm{Sr} /{ }^{86} \mathrm{Sr}=1-2 \times 10^{-4}$ where $\delta^{87} \mathrm{Sr} /{ }^{86} \mathrm{Sr}={ }^{87} \mathrm{Sr} /{ }^{86} \mathrm{Sr}$ of the sample $-{ }^{87} \mathrm{Sr}{ }^{86} \mathrm{Sr}$ of contemporaneous sea water.

These results differ from the only other two Mediterranean sections where the Sr isotope ratios of preevaporite sediments have been measured (Flecker and Ellam, 1999; McKenzie et al., 1988; Müller and Mueller, 1991; Müller et al., 1990) which have significantly larger $\delta^{87} \mathrm{Sr} /{ }^{86} \mathrm{Sr}$ from late Tortonian times (Fig. 3). Neither of these anomalous sections have yet been tied into the astronomical timescale. Moreover, they do not show a typical Mediterranean stratigraphy because the marl-limestone cycles are replace by a much more clastic-rich succession that also contains marl horizons.

These data and the time-slice geochemical maps of available ${ }^{87} \mathrm{Sr} /{ }^{86} \mathrm{Sr}$ suggest that at various times in its Late Miocene history the Mediterranean was behaving as a series of sub-basins only some of which were connected to each other and the global oceans. There are also preliminary indications suggesting that the onset of evaporite precipitation in the Mediterranean is marked by a transgression i.e. a return to oceanic ${ }^{87} \mathrm{Sr}{ }^{86} \mathrm{Sr}$. While more evidence is required to substantiate this observation, a sudden influx of seawater is in good accord with the abrupt lithological transition and the change in ocean chemistry it demands.

\section{Conclusions}

- There is evidence for isolation of at least two Mediterranean sub-basins prior to the deposition of Messinian evaporites.

- Sr isotope records from sections that have been correlated to an astronomical time scale show normal oceanic values up to and including the Lower Evaporites. Anomalous ${ }^{87} \mathrm{Sr} /{ }^{86} \mathrm{Sr}$ records have thus far been derived from sections that do not show the typical Mediterranean stratigraphy.

- Further work is required to evaluate preliminary observations which suggest initiation of evaporite precipitation was associated with a marine transgression.

\section{References}

Albarede, F., and A. Michard, 1987, Evidence for slowly changing ${ }^{87} \mathrm{Sr} / 86 \mathrm{Sr}$ in runoff from freshwater limestones of southern France.: Chemical Geology, v. 64, p. 55-65.

Berggren, W. A., D. V. Kent, C. C. Swisher III, and M.-P. Aubrey, 1995, A revised geochronology and chronostratigraphy, in W. A. Berggren, D. V. Kent, M.-P. Aubrey, and J. Hardenbol, eds., Geochronology, time scales and global stratigraphic correlation, Society of Economic Paleontologists and Mineralogists Special Publications, p. 129-212.

Brass, G. W., 1976, The variation of the marine ${ }^{87} \mathrm{Sr} /{ }^{86} \mathrm{Sr}$ ratio during Phanerozoic time: Interpretation using a flux model: Geochim. Cosmochim, Acta, v. 40, p. 721-730. 
DePaolo, D. J., and B. L. Ingram, 1985, High-resolution stratigraphy with strontium isotopes: Science, v. 227 , p. 938-941.

Flecker, R., and R. M. Ellam, 1999, Distinguishing climatic and tectonic signals in the sedimentary successions of marginal basins using Sr isotopes: an example from the Messinian salinity crisis, Eastern Mediterranean: Journal of the Geological Society, London, v. 156, p. 847-854.

Hess, J., M. L. Bender, and J.-G. Schilling, 1986, Evolution of the ratio of Strontium- 87 to Strontium-86 in seawater from the Cretaceaous to the present: Science, v. 231, p. 979-984.

Howarth, R., and J. M. McArthur, 1997, *Statistics for Strontium Isotope Stratigraphy: a robust LOWESS fit to the marine Sr-isotope curve for 0 to $206 \mathrm{Ma}$, with look-up table for derivation of numeric age: Journal of Geology, v. 105, p. 441-456.

Hsü, K. J., L. Montadert, D. Bernoulli, M. Bianca Cita, A. Erickson, R. E. Garrison, R. B. Kidd, F. Mèlierés, C. Müller, and R. Wright, 1977, History of the Mediterranean salinity crisis: Nature, v. 267, p. 399-403.

Krijgsman, W., F. J. Hilgen, C. G. Langereis, A. Santarelli, and W. J. Zachariasse, 1995, Late Miocene magnetostratigraphy, biostratigraphy and cyclostratigraphy in the Mediterranean: Earth and Planetary Science Letters, v. 136, p. 475-494.

Krijgsman, W., F. J. Hilgen, I. Raffi, F. J. Sierro, and D. S. Wilson, 1999, Chronology, causes and progression of the Messinian salinity crisis: Nature, v. 400, p. 652-655.

McKenzie, J. A., D. A. Hodell, P. A. Mueller, and D. W. Mueller, 1988, Application of strontium isotopes to late Miocene-early Pliocene stratigraphy: Geology, v. 16, p. 1022-1025.

Müller, D. W., and P. A. Mueller, 1991, Origin and age of the Mediterranean Messinian evaporites:implications form $\mathrm{Sr}$ isotopes: Earth and Planetary Science Letters, v. 107, p. 1-12.

Müller, D. W., P. A. Mueller, and J. A. McKenzie, 1990, *Strontium isotopic ratios as fluid tracers in Messinian evaporites of the Tyrrhenian sea (western Mediterranean sea): Proceedings of the Ocean Drilling Program, Scientific Results, v. 107, p. 603-614.

Palmer, M. R., and J. M. Edmond, 1989, The strontium isotope budget of the modern ocean: Earth and Planetary Science Letters, v, 92, p. 11-26.

Palmer, M. R., and H. Elderfield, 1985, Sr isotope compositio of sea water over the past 75 Myr.: Nature, v. 314, p. $526-528$. 